\title{
Selective Catalytic Ammonia Oxidation to Nitrogen by Atomic Oxygen Species on $\mathrm{Ag}(111)$
}

\author{
Mustafa Karatok, ${ }^{\dagger}$ Evgeny I. Vovk, ${ }^{\dagger, \S, \|_{\odot}}$ Ali Vala Koc, ${ }^{\dagger}$ and Emrah Ozensoy, ${ }^{\dagger}{ }^{\dagger}$, \\ ${ }^{\dagger}$ Chemistry Department and ${ }^{\ddagger}$ UNAM—National Nanotechnology Center, Bilkent University, 06800 Bilkent, Ankara, Turkey \\ ${ }^{\S}$ Boreskov Institute of Catalysis, 630090 Novosibirsk, Russian Federation
}

\section{Supporting Information}

ABSTRACT: Ammonia-selective catalytic oxidation was studied on the planar $\operatorname{Ag}(111)$ single-crystal model catalyst surface under ultra-highvacuum (UHV) conditions. A variety of oxygen species were prepared via ozone decomposition on pristine $\operatorname{Ag}(111)$. Surface coverages of oxygen species were quantified by temperature-programmed desorption (TPD) and X-ray photoemission spectroscopy techniques. Exposure of ozone on $\mathrm{Ag}(111)$ at $140 \mathrm{~K}$ led to a surface atomic oxygen $\left(\mathrm{O}_{\mathrm{a}}\right)$ overlayer. Lowenergy electron diffraction experiments revealed that annealing of this atomic oxygen-covered $\operatorname{Ag}(111)$ surface at $473 \mathrm{~K}$ in UHV resulted in the formation of ordered oxide surfaces $\left(\mathrm{O}_{\mathrm{ox}}\right)$ with $\mathrm{p}(5 \times 1)$ or $\mathrm{c}(4 \times 8)$ surface structures. Ammonia interactions with $\mathrm{O} / \mathrm{Ag}(111)$ surfaces monitored by temperature-programmed reaction spectroscopy indicated that disordered surface atomic oxygen selectively catalyzed $\mathrm{N}-\mathrm{H}$ bond cleavage, yielding mostly $\mathrm{N}_{2}$ along with minor amounts of $\mathrm{NO}$ and $\mathrm{N}_{2} \mathrm{O}$. Higher coverage $\mathrm{O} / \mathrm{Ag}(111)$ surfaces, whose structure was tentatively assigned to a bulklike amorphous silver oxide $\left(\mathrm{O}_{\text {bulk }}\right)$, showed high selectivity toward $\mathrm{N}_{2} \mathrm{O}$ formation (rather than $\mathrm{N}_{2}$ ) due to its augmented oxygen density. In contrast, ordered surface oxide overlayers on $\operatorname{Ag}(111)$ (where the order was achieved by annealing the oxygen adlayer to $473 \mathrm{~K}$ ) showed only very limited reactivity toward ammonia. The nature of the adsorbed $\mathrm{NH}_{3}$ species on a clean $\mathrm{Ag}(111)$ surface and its desorption characteristics were also investigated via infrared reflection absorption spectroscopy and TPD techniques. Current findings demonstrate that the $\mathrm{Ag}(111)$ surface can selectively oxidize $\mathrm{NH}_{3}$ to $\mathrm{N}_{2}$ under well-defined experimental conditions without generating significant quantities of environmentally toxic species such as $\mathrm{NO}_{2}, \mathrm{NO}$, or $\mathrm{N}_{2} \mathrm{O}$.

\section{INTRODUCTION}

Ammonia is an environmental pollutant whose exposure above $300 \mathrm{ppm}$ is known to cause significant health risks such as lung diseases. ${ }^{1,2}$ European Environment Agency (EEA) reports indicate that the biggest contribution to ammonia emissions originates from agricultural activities ${ }^{3}$ while power plants and transportation are among other major sources of environmentally toxic ammonia in the atmosphere. ${ }^{4}$ The effects of ammonia on the ecosystem as an environmental pollutant were also reviewed comprehensively by Fangmeier et al. ${ }^{4}$ Various technologies have been developed for gas-phase ammonia abatement. ${ }^{5}$ Selective catalytic oxidation (SCO) of ammonia is a technology which can be used as an environmentally friendly method of ammonia abatement where $\mathrm{N}_{2}$ and $\mathrm{H}_{2} \mathrm{O}$ are produced as the major products. Both transition metals ${ }^{6-10}$ and noble metals ${ }^{11-16}$ were utilized as catalysts in the SCO of ammonia. Various catalytic systems in SCO of ammonia, including noble metals, transition metal oxides, and modified zeolites, were reviewed by Chmielarz et al. ${ }^{17}$ Among these metals, silver is considered as a promising low-temperature catalyst due to its high activity and high $\mathrm{N}_{2}$ selectivity. ${ }^{14,18}$ The catalytic effect of silver nanoparticles on SCO reactions as well as their interactions with other metal systems were also investigated in the literature. ${ }^{6,12,19,20}$ However, a detailed fundamental understanding of the ammonia SCO reaction mechanism on silver single crystals at the atomic/molecular level is still missing. As can be seen in the principal ammonia oxidation reactions given in eqs $1-3$, the product distribution in ammonia SCO reaction depends on the active oxygen quantity, and thus, understanding the nature of oxygen is critical in terms of the selectivity of the catalyst. Some of the proposed mechanisms of the ammonia SCO process can be found in the literature. ${ }^{17}$ Technical ammonia SCO catalysts including silver nanoparticles as active sites reveal silver facets dominated by the (111) orientation. ${ }^{21}$ Thus, it is essential to elucidate the reactivity of the $\operatorname{Ag}(111)$ single crystal model catalyst surfaces in the ammonia SCO reaction.

$$
\begin{aligned}
& 4 \mathrm{NH}_{3}+3 \mathrm{O}_{2} \rightarrow 2 \mathrm{~N}_{2}+6 \mathrm{H}_{2} \mathrm{O} \\
& 2 \mathrm{NH}_{3}+2 \mathrm{O}_{2} \rightarrow \mathrm{N}_{2} \mathrm{O}+3 \mathrm{H}_{2} \mathrm{O} \\
& 4 \mathrm{NH}_{3}+5 \mathrm{O}_{2} \rightarrow 4 \mathrm{NO}+6 \mathrm{H}_{2} \mathrm{O}
\end{aligned}
$$

Received: August 19, 2017

Revised: September 18, 2017

Published: September 20, 2017 
The $\mathrm{O} / \mathrm{Ag}(111)$ system is an important catalytic system which has been thoroughly investigated within the context of different catalytic reactions in the past few decades both experimentally $^{22-32}$ and theoretically. ${ }^{33-38}$ However, recent studies indicate that the $\mathrm{O} / \mathrm{Ag}(111)$ structure proves to be an elusive system to understand in a comprehensive manner at the atomic scale. ${ }^{39-46}$ Oxygen-containing $\mathrm{Ag}(111)$ surfaces are known to undergo surface reconstruction readily. The most commonly observed reconstruction of this system is the $p(4 \times 4)$ structure, which was first observed by Rovida et al. ${ }^{22}$ The atomic structure of the $\mathrm{p}(4 \times 4)$ reconstruction was revised in $2000,{ }^{47}$ and an even more recent model was proposed by Schnadt et al. in $2006 .^{37}$ In addition, other reconstructions of the $\mathrm{O} / \mathrm{Ag}(111)$ system were also observed, such as $(\sqrt{ } 3 \times \sqrt{3})$ $R 30^{\circ},{ }^{48} \mathrm{c}(3 \times 5 \sqrt{3}) \mathrm{rect}^{37}(7 \times 7),{ }^{32} \mathrm{c}(4 \times 8),{ }^{38}$ and $\mathrm{p}(4 \times 5 \sqrt{3})$ rect structures. ${ }^{38}$ The reconstruction process of the $\mathrm{Ag}(111)$ surface was reviewed by Michaelides et al. ${ }^{49}$ As will be described below, none of these reconstructions besides $c(4 \times 8)$ were observed in the current study, presumably due to the use of a particularly different atomic oxygen dosing method comprised of ozone as the active atomic oxygen delivery agent. To the best of our knowledge, the ozone decomposition method was not used on $\mathrm{Ag}(111)$ single-crystal surfaces under UHV conditions in any of the former studies in the literature.

$\mathrm{O}_{2}$ dissociation is not observed on the $\mathrm{Ag}(111)$ surface under UHV conditions due to the extremely low sticking coefficient of the oxygen molecule $\left(\mathrm{ca} . \sim 10^{-6}\right)$ on the $\mathrm{Ag}(111)$ surface at low pressures. $^{26}$ The minimum pressure for the observation of molecular oxygen dissociation on $\operatorname{Ag}(111)$ was reported to be $10^{-3}$ Torr in the literature. ${ }^{24,44}$ Thus, in most of the former studies, high-pressure $\mathrm{O}_{2}$ exposures were used to investigate the nature of oxygen on a $\mathrm{Ag}(111)$ model catalyst surface. ${ }^{25-29,32}$ Other methods were also utilized for atomic oxygen delivery onto the $\mathrm{Ag}(111)$ surface under UHV conditions, such as $\mathrm{NO}_{2}$ decomposition $^{31,36,38,40,47,50}$ and thermal gas cracking. ${ }^{41,42,45}$ Ozone decomposition is an extremely efficient method for dosing high concentrations of oxygen atoms on metal surfaces under UHV conditions (i.e., in the absence of elevated-pressure exposures). Efficient atomic oxygen delivery onto single-crystal model catalyst surfaces with ozone was successfully carried out for $\mathrm{Al}(111),{ }^{51} \mathrm{Pd}(111),{ }^{52} \mathrm{Pt}(111),{ }^{52,53}$ and $\mathrm{Au}(111) .{ }^{52,54}$ With this method, atomic oxygen can be accumulated on singlecrystal surfaces even at pressures on the order of $10^{-10}$ Torr, while significantly minimizing the introduction of unwanted contaminations onto the catalyst surface. High-pressure oxygen accumulation leads to surface reconstruction and oxide formation rather than the generation of a mobile surface atomic oxygen overlayer on $\mathrm{Ag}(111)$. Heine et al. reported that oxide formation was observed to be more facile on the surface regions with high step density ${ }^{44}$ whose generation can be triggered by high-pressure $\mathrm{O}_{2}(\mathrm{~g})$. Thus, atomic oxygen accumulation under UHV conditions may limit oxide formation and allow exclusive investigation of high-coverage surface oxygen overlayers on $\operatorname{Ag}(111)$. Along these lines, an important advantage of ozone utilization over other atomic oxygen delivery vectors such as $\mathrm{NO}_{2}$ decomposition is the fact that the ozone decomposition method enables the use of a greater variety of surface coverages of atomic oxygen species.

In the current work, we focus on the reactivity of oxygen atoms and oxide overlayers in ammonia SCO reactions on $\mathrm{Ag}(111)$ and report new catalytic structure-functionality relationships at the molecular level. We believe that the current findings may also provide valuable insights regarding the nature of oxygen on $\operatorname{Ag}(111)$ which can also possibly be extrapolated to other crucial heterogeneous catalytic processes such as partial oxidation reactions of ethylene and methanol. ${ }^{27,57,71}$

\section{EXPERIMENTAL SECTION}

Experiments were performed in a custom-made UHV chamber with a base pressure of $2 \times 10^{-10}$ Torr which is equipped with $\mathrm{X}$-ray photoemission spectroscopy (XPS; Riber $\mathrm{Mg} / \mathrm{Al}$ dual anode with a Riber EA150 electron energy analyzer), lowenergy electron diffraction (LEED; custom-made), infrared reflection absorption spectroscopy (IRAS; Bruker Tensor 37 with custom-design external IR optics and a tailor-made $\mathrm{N}_{2}$ purge box, $4 \mathrm{~cm}^{-1}$ resolution, 100 scans, $10 \mathrm{kHz}$ scanner velocity, mercury cadmium telluride (MCT) detector), temperature-programmed desorption (TPD), and temperature-programmed reaction spectroscopy (TPRS) capabilities. A quadrupole mass spectrometer (QMS; Ametek Dycor Dymaxion DM200) and a proportional-integral-derivative (PID)-controlled linear sample heater (Heatwave, model 101303) were used for the TPD/TPRS experiments. All of the TPD/TPRS experiments were performed with a heating rate of $1 \mathrm{~K} / \mathrm{s}$, a 70 eV QMS beam energy, and a $30 \mathrm{~ms}$ dwell time for each desorption channel. The $\mathrm{Ag}(111)$ single-crystal sample $(10 \mathrm{~mm}$ diameter $\times 1 \mathrm{~mm}$ thick disk, both sides polished, purity $>99.999 \%$, MaTeck $\mathrm{GmbH}$ ) was affixed on Ta wires, through which the sample could be resistively heated to $1073 \mathrm{~K}$. The cooling of the sample was achieved via a liquid nitrogen reservoir located inside the sample manipulator probe holding the $\operatorname{Ag}(111)$ single crystal. The temperature of the sample was measured using a K-type thermocouple spot-welded on the lateral facet of the $\operatorname{Ag}(111)$ disk. The $\operatorname{Ag}(111)$ sample surface was cleaned by cycles of $\mathrm{Ar}^{+}$sputtering $(\mathrm{Ar}(\mathrm{g})$, Linde $\mathrm{AG}$, purity $\geq 99.999 \%$ ) with a sputtering gun (LK Technologies, NGI3000, $1.5 \mathrm{kV} \times 15 \mathrm{~mA}$ ) at room temperature followed by annealing at $773 \mathrm{~K}$ in UHV for $20 \mathrm{~min}$. After $\mathrm{Ar}^{+}$sputtering, the $\mathrm{Ag}(111)$ sample was exposed to ozone $\left(2.0 \times 10^{-9}\right.$ Torr $\times 5$ $\mathrm{min}$ ) at room temperature for further cleaning followed by annealing to $773 \mathrm{~K}$ for adsorbed oxygen removal. The cleanness of the surface prior to experiments was confirmed by XPS and LEED. An Al K $\alpha$ X-ray source $(1486.6 \mathrm{eV}, 10 \mathrm{kV} \times 20 \mathrm{~mA}$ ) was used in the XPS measurements. O $1 \mathrm{~s}$ and $\mathrm{Ag} 3 \mathrm{~d}$ regions were analyzed with an energy resolution of $0.1 \mathrm{eV}$ for 10 scans and 5 scans, respectively. All of the XPS $O$ 1s signals were positioned and normalized using the $\mathrm{Ag} 3 \mathrm{~d}$ signals that were measured along with the $\mathrm{O}$ 1s signal.

Atomic oxygen was accumulated on the $\operatorname{Ag}(111)$ model catalyst surface by ozone exposure using a methodology whose details can be found in one of our former papers. ${ }^{55}$ Ozone was dosed to the UHV system via Teflon tubings and a highprecision leak valve. $\mathrm{NH}_{3}$ gas (Linde AG, purity $\geq 99.995 \%$ ) was used without further purification and introduced onto the $\operatorname{Ag}(111)$ surface via a separate leak valve. In the rest of the text, exposures of adsorbate species $(\varepsilon)$ are given in langmuirs (1 langmuir $=1 \times 10^{-6}$ Torr $\left.\cdot \mathrm{s}\right)$ and the estimated surface coverages $(\theta)$ of the corresponding adsorbates are reported in monolayer equivalents (MLE).

\section{RESULTS AND DISCUSSION}

Oxygen on $\mathrm{Ag}$ (111). Before the investigation of SCO of $\mathrm{NH}_{3}$ with oxygen, the behavior of oxygen species generated upon ozone decomposition on a clean $\mathrm{Ag}(111)$ single-crystal model catalyst surface was studied via TPD. For this purpose, 
increasing exposures of ozone were introduced on $\operatorname{Ag}(111)$ at $140 \mathrm{~K}$, and the TPD spectra of molecular oxygen $(\mathrm{m} / z=32)$ desorbing from the $\operatorname{Ag}(111)$ single-crystal surface as a function of temperature were acquired as shown in Figure 1a. As can be
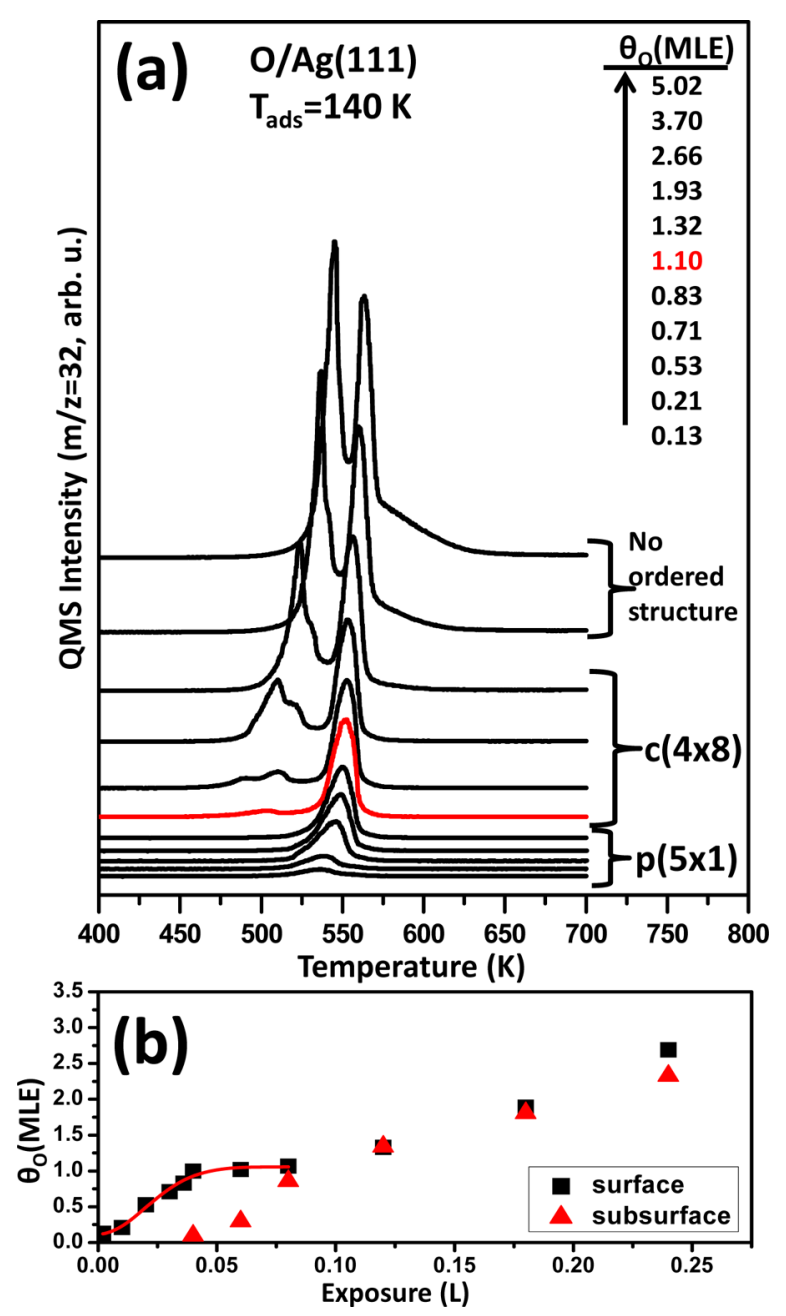

Figure 1. (a) TPD profiles for oxygen desorption $(m / z=32)$ obtained by increasing ozone exposures on clean $\mathrm{Ag}(111)$ at $140 \mathrm{~K}$. (b) Relative oxygen surface coverages (obtained via integrated TPD desorption signals in part a) for surface and subsurface oxygen species on $\mathrm{Ag}(111)$ as a function of the ozone exposure.

seen in Figure 1a, oxygen desorption starts at $535 \mathrm{~K}$ for an oxygen surface coverage of $\theta_{\mathrm{O}}=0.13 \mathrm{MLE}$, and the desorption temperature slowly increases with increasing oxygen surface coverage. Furthermore, various additional low-temperature $(T$ $<525 \mathrm{~K}$ ) desorption features (e.g., see the red spectrum in Figure 1a) start to appear and grow in intensity with increasing $\theta_{\mathrm{O}}$. These features can be associated with subsurface atomic oxygen $\left(\mathrm{O}_{\text {sub }}\right)$ as previously reported in the literature. ${ }^{26,42}$ These low-temperature features do not converge to a saturation, in agreement with a former paper, ${ }^{42}$ presumably due to the diffusion of atomic oxygen into the subsurface. Campbell et al. argued that oxygen atoms could be more stable on the silver surface rather than in bulk silver oxide on the basis of the heat of adsorption of oxygen atoms on $\mathrm{Ag}(111)$ as compared to the heat of formation of bulk silver oxide. ${ }^{26}$ Therefore, bulk oxide formation due to oxygen diffusion to the silver subsurface seems to be rather unlikely at low oxygen coverages. However, formation of bulk silver oxide at high oxygen coverages is feasible and will be discussed in more detail below. Along these lines, by exploiting isotopically labeled oxygen molecules, Backx et al. showed that subsurface oxygen in the $\operatorname{Ag}(110)$ surface desorbs at lower temperatures than the surface oxygen atoms. ${ }^{56}$ TPD data for O/Ag(111) (Figure 1a) obtained via ozone decomposition are in good agreement with a former study, where $\mathrm{NO}_{2}$ decomposition was utilized for atomic oxygen delivery on $\mathrm{Ag}(111) .^{50}$ Integrated TPD signals corresponding to surface $\left(\mathrm{O}_{\mathrm{a}}\right)$ and subsurface $\left(\mathrm{O}_{\text {sub }}\right)$ oxygen species in Figure 1a were also calculated individually and plotted as a function of the ozone exposure (Figure $1 \mathrm{~b}$ ). In this latter plot, monolayer coverage reaches a plateau around 0.04 langmuir, which may be attributed to the saturation of the first overlayer on the surface. The absolute surface saturation coverage of the first oxygen monolayer on $\operatorname{Ag}(111)$ was previously calculated by Campbell et al. ${ }^{26}$ for a $(4 \times 4)-\mathrm{O} /$ $\mathrm{Ag}(111)$ surface structure at this coverage. It is worth mentioning that, in the current work, the $(4 \times 4)-\mathrm{O} / \mathrm{Ag}(111)$ structure was not observed in any of the investigated coverages, because this structure is not stable when oxygen is accumulated under UHV conditions. ${ }^{44,45}$ Nevertheless, in the current work, the saturation exposure of 0.04 langmuir was attributed to 1 MLE and was used to calibrate and quantify other desorption signals. As can be seen in Figure 1b, for the ozone exposures above 0.08 langmuir, surface oxygen coverage starts to exceed the convergence coverage of 1 MLE. This can be explained by the transformation of the surface oxygen overlayer to form a new structure with a higher oxygen density. We tentatively assign this latter structure to a bulklike silver oxide.

Analysis of the $\operatorname{Ag}(111)$ single-crystal surface after various ozone exposures at $140 \mathrm{~K}$ by LEED revealed no ordered structures, suggesting randomly located oxygen species at 140 $\mathrm{K}$ for all oxygen coverages. However, annealing of the $\mathrm{O} /$ $\mathrm{Ag}(111)$ surfaces originally prepared at $140 \mathrm{~K}$ indicated that thermal activation led to the ordered oxide formation with a $\mathrm{p}(5 \times 1)$ structure for $\theta_{\mathrm{O}}<1.10 \mathrm{MLE}$ (Figure $2 \mathrm{a}, \mathrm{b}$ ), as well as an additional oxide structure which can be tentatively assigned to a

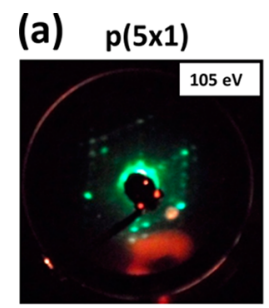

(b)

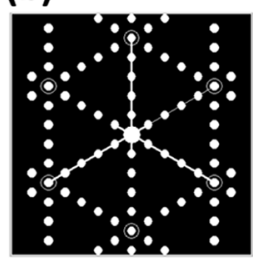

(c) $c(4 \times 8)$

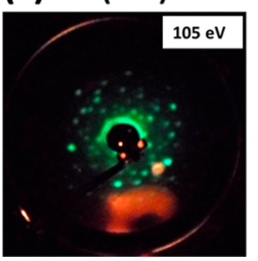

(d)

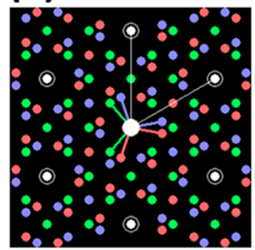

Figure 2. LEED images of $\mathrm{O} / \mathrm{Ag}(111)$ overlayers obtained by introducing different ozone exposures at $140 \mathrm{~K}$ on a clean $\mathrm{Ag}(111)$ surface followed by pumping and annealing to $473 \mathrm{~K}$ in UHV. (a) LEED image of the $\mathrm{p}(5 \times 1)-\mathrm{O} / \mathrm{Ag}(111)$ overlayer $\left(\theta_{\mathrm{O}}=0.83 \mathrm{MLE}\right)$ and (b) its simulated (theoretical) LEED pattern. (c) LEED image of the $c(4 \times 8)-\mathrm{O} / \mathrm{Ag}(111)$ overlayer $\left(\theta_{\mathrm{O}}=1.10 \mathrm{MLE}\right)$ and (d) its simulated (theoretical) LEED pattern. 
$\mathrm{c}(4 \times 8)$ structure appearing at $1.10 \mathrm{MLE}<\theta_{\mathrm{O}}<1.93 \mathrm{MLE}$ (Figure 2c,d). Oxide formation due to the annealing of oxygen overlayers on $\operatorname{Ag}(111)$ was also previously observed by Bukhtiyarov et al., 29 where it was demonstrated via XPS that atomic oxygen adsorbed on $\mathrm{Ag}(111)$ at $300 \mathrm{~K}$ can form silver oxide when the sample is heated to $420 \mathrm{~K}$. LEED images in Figure 2 were obtained by dosing different exposures of ozone on $\operatorname{Ag}(111)$ at $473 \mathrm{~K}$ (i.e., a temperature which is slightly below the beginning of the oxygen desorption) followed by pumping and cooling the sample to $140 \mathrm{~K}$ for LEED analysis. It is worth mentioning that ozone accumulation using relevant exposures at $140 \mathrm{~K}$ and heating to $473 \mathrm{~K}$ yielded LEED images identical to that of direct ozone dosing at $473 \mathrm{~K}$. Starting from the lowest oxygen coverage (i.e., $\theta_{\mathrm{O}}=0.13 \mathrm{MLE}$ ) up to $\theta_{\mathrm{O}}=1.10$ MLE, sharp spots of the $\mathrm{p}(5 \times 1)$ structure were detectable after annealing at $473 \mathrm{~K}$. For $\theta_{\mathrm{O}} \geq 1.10 \mathrm{MLE}$, another ordered LEED structure started to appear after annealing at $473 \mathrm{~K}$ along with the emergence of the subsurface oxygen signals in TPD (red spectrum in Figure 1a). We tentatively assigned this structure to a $c(4 \times 8)$ overlayer consisting of three separate domains rotated by $120^{\circ}$ with respect to each other. These domains are color-coded in the theoretical LEED pattern given in Figure 2 d. $\mathrm{c}(4 \times 8)$ reconstruction on $\mathrm{O} / \mathrm{Ag}(111)$ was also observed by Schnadt and co-workers via scanning tunneling microscopy (STM) and was associated with a significantly oxidized silver structure. ${ }^{38}$ In the current study, the $c(4 \times 8)$ structure was only observed at relatively high oxygen coverages (i.e., 1.10 MLE $<\theta_{\mathrm{O}}<1.93 \mathrm{MLE}$ ) where the surface oxygen species converged to a constant value (black curve in Figure 1b) while subsurface oxygen monotonically increased (red curve in Figure $1 \mathrm{~b}$ ). For $\theta_{\mathrm{O}}>1.93$ MLE, LEED images became extremely fuzzy, suggesting the lack of an ordered structure at high coverages. This fuzzy structure may be associated with an amorphous bulklike oxide structure. Current results are in good agreement with the density functional theory (DFT) calculations of $\mathrm{Li}$ et al., who proposed that increasing oxygen coverages on the $\operatorname{Ag}(111)$ surface by ozone exposure might lead to ordered atomic oxygen overlayers followed by oxide-like thick films at higher $\theta_{\mathrm{O}}{ }^{33}$ In a related study, Martin et al. deposited atomic oxygen on $\operatorname{Ag}(111)$ by thermal cracking of $\mathrm{O}_{2}(\mathrm{~g})$ at $500 \mathrm{~K}$ with $P_{\mathrm{O}_{2}}=10^{-7}$ mbar. ${ }^{41}$ They reported bulklike silver oxide formation at high $\theta_{\mathrm{O}}$ and argued that the $\mathrm{c}(4 \times 8)$ overlayer is the precursor state for bulklike silver oxide formation.

Oxygen accumulation on the $\operatorname{Ag}(111)$ surface at $140 \mathrm{~K}$ was also analyzed by XPS. O 1s spectra of the $\mathrm{O} / \mathrm{Ag}(111)$ surface as a function of increasing oxygen coverage are given in Figure 3. Due to the detection limit of our photoelectron detector, we were able to observe a reliable $\mathrm{O} 1 \mathrm{~s}$ signal at $\theta_{\mathrm{O}} \geq 0.53$ MLE. Signals in the region between 530 and $531 \mathrm{eV}$ were assigned to atomic oxygen either on the surface $\left(\mathrm{O}_{\mathrm{a}}\right)$ or in the subsurface $\left(\mathrm{O}_{\text {sub }}\right)$, whereas surface oxide $\left(\mathrm{O}_{\mathrm{ox}}\right)$ signals were found between 528.1 and $528.5 \mathrm{eV}^{26-30,38-40,44,50,37}$ As mentioned above, ordered surface oxide $\left(\mathrm{O}_{\mathrm{ox}}\right)$ species were not detectable at 140 $\mathrm{K}$ according to LEED experiments. Schlögl and co-workers previously reported that the $\mathrm{O} 1 \mathrm{~s}$ signal of bulk silver oxide appeared at $529.0 \mathrm{eV} .^{58}$ In another study, Heine et al. assigned an $\mathrm{O} 1 \mathrm{~s}$ signal at $528.9 \mathrm{eV}$ to silver oxide species at the step edges of the $\operatorname{Ag}(111)$ surface $^{44}$ and suggested that subsurface oxygen increases the step density of the $\mathrm{Ag}(111)$ surface. In Figure 3, a noticeable increase in the $\mathrm{O} 1 \mathrm{~s}$ signal at ca. $529 \mathrm{eV}$ is visible at $\theta_{\mathrm{O}} \geq 1.10 \mathrm{MLE}$ (i.e., in correlation with the

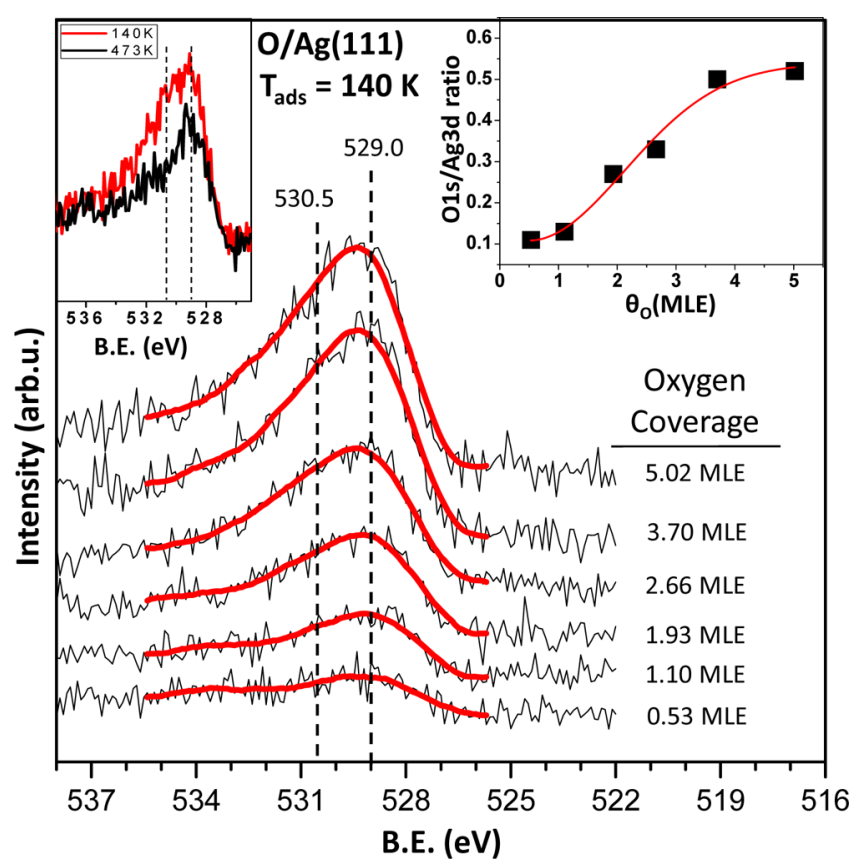

Figure 3. $\mathrm{O}$ 1s XPS spectra of $\mathrm{O} / \mathrm{Ag}(111)$ as a function of increasing oxygen coverage obtained by increasing exposures of ozone at $140 \mathrm{~K}$. The inset on the right shows the integrated $\mathrm{O} 1 \mathrm{~s} / \mathrm{Ag} 3 \mathrm{~d}$ signal ratio as a function of the oxygen coverage. The inset on the left shows the $\mathrm{O}$ 1s XPS spectra for $\mathrm{O} / \mathrm{Ag}(111)$ with $\theta_{\mathrm{O}}=2.66 \mathrm{MLE}$ dosed at $140 \mathrm{~K}$ (red) and dosed at $473 \mathrm{~K}$ (black).

appearance of the subsurface oxygen features in TPD data given in Figure 1a). This O 1s feature at ca. $529 \mathrm{eV}$ may be associated with disordered oxide and/or amorphous bulklike oxide $\left(\mathrm{O}_{\text {bulk }}\right)$ species. Indications of the formation of bulklike silver oxide species were also present in the Ag 3d XPS spectra (Figure S1, Supporting Information), revealing a broadening in the full width at half-maximum (fwhm) of the $\mathrm{Ag} 3 \mathrm{~d}$ peak with increasing oxygen coverages $\theta_{\mathrm{O}}>1.90 \mathrm{MLE}$. Broadening of the $\mathrm{Ag} 3 \mathrm{~d}$ XPS signal due to the formation of silver oxide was also previously reported by Bukhtiyarov et al. ${ }^{29}$

The inset on the right-hand side of Figure 3 shows the variation of the $\mathrm{O} 1 \mathrm{~s} / \mathrm{Ag} 3 \mathrm{~d}$ integrated signal ratios in XPS as a function of oxygen coverage calculated from the ozone exposure values using the TPD data in Figure 1. It is apparent that the $\mathrm{O} 1 \mathrm{~s} / \mathrm{Ag} 3 \mathrm{~d}$ integrated signal ratio reaches a convergence for $\theta_{\mathrm{O}} \geq 3.70 \mathrm{MLE}$ (Figure 3) while the total $m / z=32$ TPD desorption signal intensity still continues to increase within this coverage window (Figure 1b). These observations may indicate continuous transport of oxygen species toward the subsurface region (i.e., possibly below $10 \mathrm{~nm}$ of the surface) of the $\mathrm{O} / \mathrm{Ag}(111)$ system at high oxygen coverages which cannot be readily detectable by the surfacesensitive XPS technique. It should be noted that X-ray-induced oxygen desorption during XPS analysis could also contribute to the high-coverage convergence of the $\mathrm{O} 1 \mathrm{~s} / \mathrm{Ag} 3 \mathrm{~d}$ signal ratio.

The $\mathrm{O} 1 \mathrm{~s}$ signal of the $2.66 \mathrm{MLE} \mathrm{O} / \mathrm{Ag}(111)$ surface obtained at $140 \mathrm{~K}$ was also compared to the analogous surface prepared at $473 \mathrm{~K}$ using an identical ozone exposure. These results are shown in the left-hand-side inset of Figure 3 (red and black spectra, respectively). It is apparent that the $\mathrm{O} 1 \mathrm{~s}$ spectrum corresponding to $473 \mathrm{~K}$ reveals attenuated features at ca. 529 and ca. $530.5 \mathrm{eV}$, which may be attributed to the partial loss of bulklike oxide $\left(\mathrm{O}_{\text {bulk }}\right)$ and surface/subsurface $\left(\mathrm{O}_{\mathrm{a}} / \mathrm{O}_{\text {sub }}\right)$ 
atomic oxygen species, respectively. The $\mathrm{O} 1 \mathrm{~s}$ feature at $529 \mathrm{eV}$ corresponding to bulklike oxide species shows relatively less significant attenuation. These observations indicate transport of oxygen from the surface and subsurface regions of silver toward the bulk upon thermal activation provided by annealing at 473 K.

Other than the $\mathrm{O}$ 1s signals due to surface atomic oxygen $\left(\mathrm{O}_{\mathrm{a}}\right)$ and bulklike oxide $\left(\mathrm{O}_{\text {bulk }}\right)$ species, a less prominent shoulder at $532 \mathrm{eV}$ is also detectable in the $\mathrm{O} 1 \mathrm{~s}$ spectra presented in Figure 3 which can be associated with hydroxide (minority) species due to background water adsorption. Note that the presence of physisorbed oxygen species can be readily excluded due to the extremely low desorption temperature of such species (i.e., $\sim 50 \mathrm{~K}) .^{26}$

Ammonia on $\mathrm{Ag}$ (111). Ammonia adsorption was carried out on the clean $\operatorname{Ag}(111)$ surface at $90 \mathrm{~K}$, and the $\mathrm{m} / z=17$ signal was monitored in TPD experiments along with the $\mathrm{m} / z$ $=28,18$, and 2 signals to check the presence of potential decomposition products and water desorption from background adsorption (Figure 4). In all of the TPD experiments,

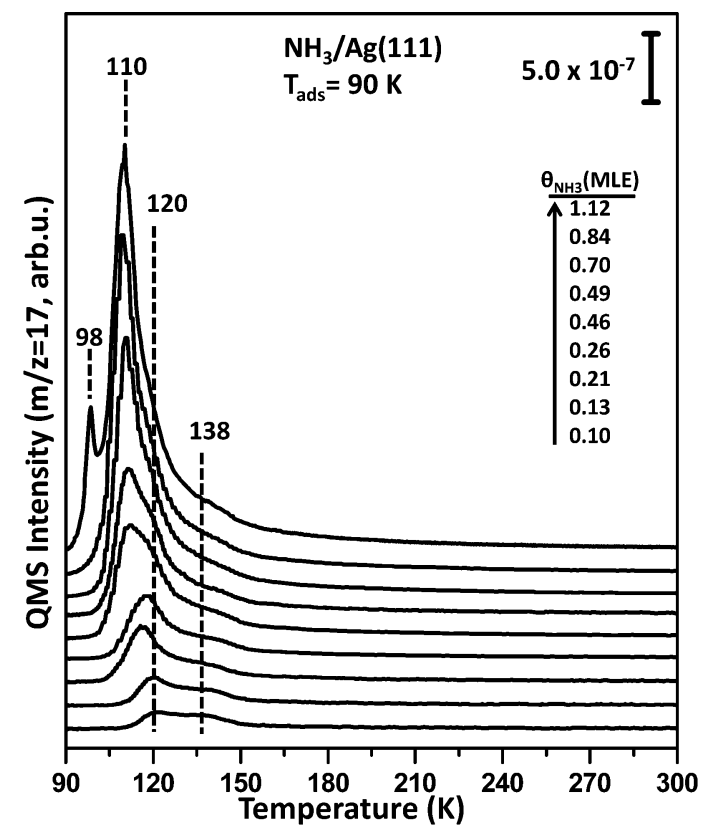

Figure 4. TPD profiles $(m / z=17)$ obtained after ammonia adsorption on a clean $\operatorname{Ag}(111)$ surface at $90 \mathrm{~K}$ as a function of increasing ammonia coverage.

ammonia was found to desorb molecularly in a reversible manner from the clean $\operatorname{Ag}(111)$ single-crystal surface, where no ammonia decomposition products, namely, $\mathrm{N}_{2}$ and $\mathrm{H}_{2}$ desorption, were detectable at any ammonia coverage. Limited background water desorption was observed, and TPD spectra for the $m / z=18$ channel are given in the Supporting Information (Figure S2). In Figure 4, two ammonia desorption maxima located at 138 and $120 \mathrm{~K}$ were observed for the lowest ammonia coverage of $\theta_{\mathrm{NH}_{3}}=0.10$ MLE. With increasing ammonia coverage, the desorption signal at $120 \mathrm{~K}$ became broader and its desorption maximum shifted to lower temperatures. Broadening and the low-temperature shift with increasing ammonia coverage in the submonolayer range are common behaviors of ammonia TPD profiles obtained from numerous metal surfaces such as $\operatorname{Pt}(111),{ }^{59} \mathrm{Au}(111),{ }^{60}$ $\mathrm{Rh}(111),{ }^{61}$ and $\operatorname{Ir}(100)^{62}$ which can be attributed to the heterogeneity of the adsorbed ammonia species, as well as repulsive interactions (or decreasing attractive interactions) between the adsorbates in the first monolayer. ${ }^{63}$ Figure 4 shows that the major ammonia desorption feature at $110 \mathrm{~K}$ reached saturation, which was immediately followed by the appearance of an additional desorption maximum at $98 \mathrm{~K}$ that can be assigned to the formation of multilayer ammonia overlayers. TPD data given in Figure 4 can be used to estimate the relative ammonia surface coverages. For this purpose, the multilayer signal at $98 \mathrm{~K}$ was deconvoluted and subtracted from the whole desorption spectrum and the integrated desorption signal between 90 and $480 \mathrm{~K}$ associated with the desorption maximum at $110 \mathrm{~K}$ was used to estimate $\theta_{\mathrm{NH}_{3}}=1 \mathrm{MLE}$. It is worth mentioning that TPD experiments were also performed for ammonia coverages greater than $1.12 \mathrm{MLE}$, revealing a typical zeroth-order desorption kinetics (data not shown). In the literature, analogous monolayer and multilayer ammonia desorption signals were also observed on other metal surfaces $^{61,62}$ as well as on $\operatorname{Ag}(110) .{ }^{64}$ The less prominent ammonia desorption signal at $138 \mathrm{~K}$ in Figure 4 can be attributed to stronger ammonia adsorption on surface defects and/or adsorption of ammonia with dissimilar geometries/ orientations on different surface adsorption sites. Overall, TPD results for $\mathrm{NH}_{3}$ adsorption on clean $\mathrm{Ag}(111)$ given in Figure 4 clearly point to the fact that, in the absence of oxygen species, $\mathrm{Ag}(111)$ is incapable of activating $\mathrm{NH}_{3}$. On the other hand, as will be shown below, ammonia activation and its selective catalytic oxidation are achievable by fine-tuning the nature and surface coverage of oxygen species on $\operatorname{Ag}(111)$.

IRAS spectra corresponding to the adsorption of ammonia on clean $\mathrm{Ag}(111)$ for various coverages of ammonia at $90 \mathrm{~K}$ are given in Figure 5. For the lowest coverage of ammonia $\left(\theta_{\mathrm{NH}_{3}}=\right.$

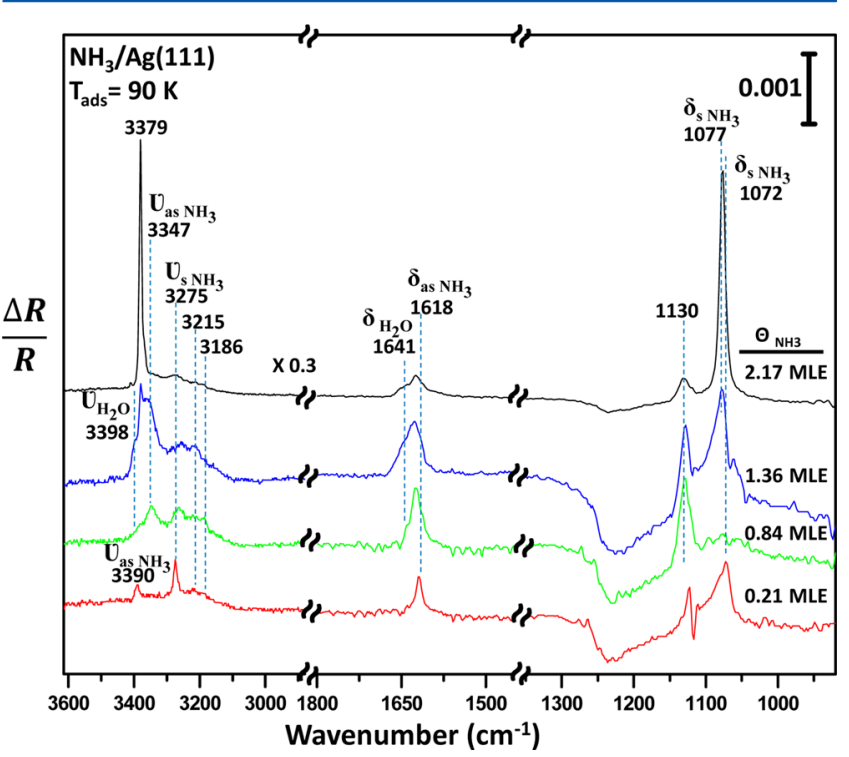

Figure 5. IRAS spectra of ammonia adsorption on a clean $\operatorname{Ag}(111)$ surface at $90 \mathrm{~K}$ as a function of the ammonia surface coverage.

$0.21 \mathrm{MLE})$, symmetric $\left(\delta_{\mathrm{s}}\right)$ and antisymmetric $\left(\delta_{\text {as }}\right) \mathrm{NH}_{3}$ deformation signals appeared at 1072 and $1618 \mathrm{~cm}^{-1}$, respectively; while symmetric $\left(\nu_{\mathrm{s}}\right)$ and antisymmetric $\left(\nu_{\mathrm{as}}\right)$ $\mathrm{NH}_{3}$ stretching modes can be seen at 3275 and $3390 \mathrm{~cm}^{-1}$, respectively. ${ }^{64}$ For submonolayer coverages, it is commonly observed that ammonia molecules are typically adsorbed on transition-metal surfaces through unpaired electrons of nitrogen 
and the molecular axis stays perpendicular to the surface. ${ }^{65}$ In such cases, $\delta_{\text {as }}$ and $\nu_{\text {as }}$ modes cannot be observed as reported in the literature for ammonia adsorption on $\mathrm{Ni}(111),{ }^{66}$ $\mathrm{Ru}(0001),{ }^{67} \mathrm{Pt}(111),{ }^{68}$ and $\mathrm{Cu}(110){ }^{69}$ In contrast, IRAS data in Figure 5 suggest that, on a clean $\operatorname{Ag}(111)$ surface, the molecular axis of ammonia is tilted with respect to the $\operatorname{Ag}(111)$ surface for submonolayer coverages. A similar behavior was also observed for ammonia adsorption on clean $\operatorname{Ag}(110)$ via electron energy loss spectroscopy (EELS). ${ }^{64}$ For the IRAS spectrum corresponding to $\theta_{\mathrm{NH}_{3}}=0.84 \mathrm{MLE}$, the $\delta_{\mathrm{s}}$ signal was found to vanish and the $\mathrm{NH}_{3}$ stretching modes were observed to broaden and shift to lower frequencies, namely, to 3347 and $3266 \mathrm{~cm}^{-1}$. These changes in the IRAS spectra are probably due to increasing intermolecular interactions between adsorbed ammonia molecules on $\operatorname{Ag}(111)$ with increasing surface coverages as well as due to the formation of hydrogen-bonding interactions. Loss of the $\delta_{\mathrm{s}}$ feature was also reported on $\mathrm{NH}_{3} /$ $\mathrm{Ru}(0001)$ by Rodriquez et al. for the second layer (i.e., multilayer) of ammonia on $\mathrm{Ru}(0001)$ and was attributed to the formation of intermolecular hydrogen bonding and/or a smaller IR absorption cross section of the ammonia molecules in the second layer. ${ }^{67}$

The IRAS spectrum corresponding to $\theta_{\mathrm{NH}_{3}}=0.84 \mathrm{MLE}$ also revealed water stretching and bending signals due to background water adsorption located at 3398 and $1641 \mathrm{~cm}^{-1}$, respectively. ${ }^{70}$ Furthermore, the IRAS signals at 3186 and 3215 $\mathrm{cm}^{-1}$ might be related to hydronium ions and hydrogenbonded water molecules located on the surface or on the ammonia overlayer with different orientations. ${ }^{70}$ When the ammonia coverage was increased to $1.36 \mathrm{MLE}$, the symmetric deformation mode $\left(\delta_{\mathrm{s}}\right)$ at $1072-1077 \mathrm{~cm}^{-1}$ reappeared and the antisymmetric $\left(\nu_{\mathrm{as}}\right) \mathrm{NH}_{3}$ stretching signal became broader. Furthermore, at $\theta_{\mathrm{NH}_{3}}=2.17 \mathrm{MLE}$, an additional sharp signal appeared at $3379 \mathrm{~cm}^{-1}$ which can be assigned to the formation of solid multilayer ammonia. ${ }^{68}$ These results are in very good agreement with the former reports in the literature for multilayer ammonia adsorption on various single crystals. ${ }^{67,71}$ Vibrational frequencies of $\mathrm{NH}_{3}$ on $\mathrm{Ag}(111)$ for different $\mathrm{NH}_{3}$ coverages obtained by the currently presented IRAS spectra are summarized in Table 1. IRAS data given in Figure 5 for $\mathrm{NH}_{3}$ / $\mathrm{Ag}(111)$ are in agreement with the corresponding TPD data presented in Figure 4, suggesting molecular adsorption (i.e.,

Table 1. Vibrational Frequency Assignments for the $\mathrm{NH}_{3}$ / $\operatorname{Ag}(111)$ IRAS Data Presented in Figure 5

\begin{tabular}{|c|c|c|c|c|}
\hline & $\begin{array}{l}\delta_{\mathrm{s}(\mathrm{HNH})} \\
\left(\mathrm{cm}^{-1}\right)\end{array}$ & $\begin{array}{c}\delta_{\mathrm{as}(\mathrm{HNH})} \\
\left(\mathrm{cm}^{-1}\right)\end{array}$ & $\begin{array}{l}\nu_{\mathrm{s}(\mathrm{NH})} \\
\left(\mathrm{cm}^{-1}\right)\end{array}$ & $\begin{array}{l}\nu_{\text {as}(\mathrm{NH})} \\
\left(\mathrm{cm}^{-1}\right)\end{array}$ \\
\hline $\begin{array}{l}\mathrm{NH}_{3} \text { on } \operatorname{Ag}(111) \\
\quad\left(\theta_{\mathrm{NH}_{3}}=0.21 \mathrm{MLE}\right)\end{array}$ & 1072 & 1618 & 3275 & 3390 \\
\hline \multirow{2}{*}{$\begin{array}{l}\mathrm{NH}_{3} \text { on } \mathrm{Ag}(111) \\
\quad\left(\theta_{\mathrm{NH}_{3}}=0.84 \mathrm{MLE}\right)\end{array}$} & & 1640 & 3266 & 3347 \\
\hline & & 1625 & & \\
\hline \multirow{2}{*}{$\begin{array}{l}\mathrm{NH}_{3} \text { on } \mathrm{Ag}(111) \\
\quad\left(\theta_{\mathrm{NH}_{3}}=1.36 \mathrm{MLE}\right)\end{array}$} & 1077 & 1625 & 3257 & 3379 \\
\hline & & 1651 & & 3358 \\
\hline \multirow{2}{*}{$\begin{array}{l}\mathrm{NH}_{3} \text { on } \mathrm{Ag}(111) \\
\quad\left(\theta_{\mathrm{NH}_{3}}=2.17 \mathrm{MLE}\right)\end{array}$} & 1077 & 1625 & 3275 & 3379 \\
\hline & & 1651 & & \\
\hline $\begin{array}{l}\mathrm{NH}_{3} \text { on } \mathrm{Ag}(110) \\
(\text { submonolayer })^{64}\end{array}$ & 1050 & 1640 & 3320 & 3400 \\
\hline solid $\mathrm{NH}_{3}{ }^{64}$ & 1060 & 1646 & 3223 & 3378 \\
\hline
\end{tabular}

lack of dissociation) of ammonia on $\operatorname{Ag}(111)$ in the absence of additional oxygen species.

Ammonia SCO on O/Ag(111). The ammonia SCO reaction was carried out on $\mathrm{O} / \mathrm{Ag}(111)$, and the resulting products were followed in TPRS experiments. To prevent poisoning of the $\mathrm{O} / \mathrm{Ag}(1111)$ surface with excess ammonia, $\mathrm{NH}_{3}$ was dosed on the $\mathrm{O} / \mathrm{Ag}(111)$ at $250 \mathrm{~K}$ (i.e., at a temperature above the desorption maximum of the first monolayer of ammonia on clean $\operatorname{Ag}(111))$. During TPRS experiments, $m / z=17\left(\mathrm{NH}_{3}\right), 28\left(\mathrm{~N}_{2}\right), 30(\mathrm{NO}), 44\left(\mathrm{~N}_{2} \mathrm{O}\right)$, $46\left(\mathrm{NO}_{2}\right), 32\left(\mathrm{O}_{2}\right), 18\left(\mathrm{H}_{2} \mathrm{O}\right)$, and $2\left(\mathrm{H}_{2}\right)$ desorption channels were simultaneously monitored.

Two different sets of TPRS spectra for the oxygen-ammonia reaction are presented in Figure 6, where the main difference

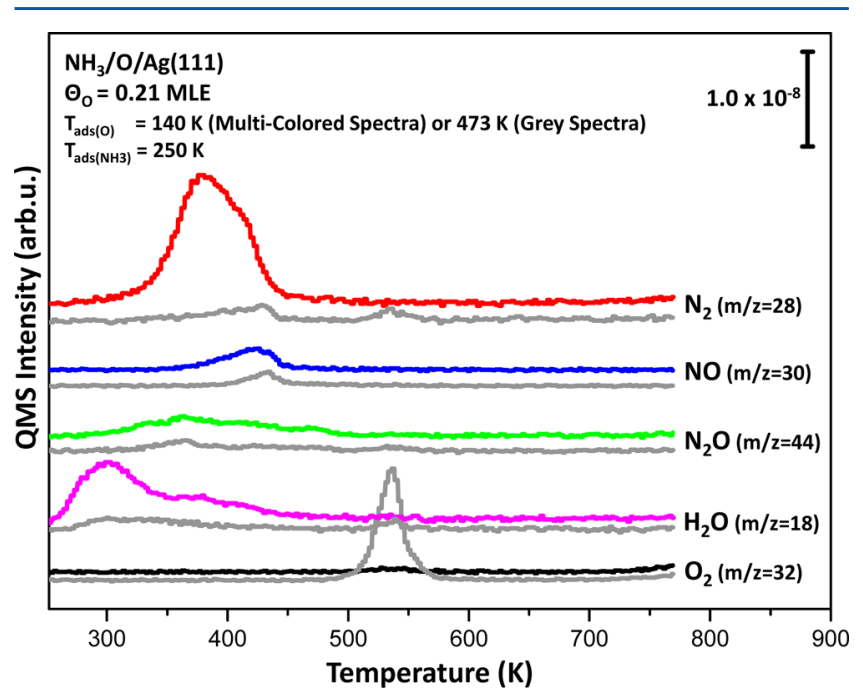

Figure 6. TPRS profiles for the reaction of ammonia with oxygen on $\mathrm{Ag}(111)$. In all of the experiments, an identical exposure of $\mathrm{NH}_{3}\left(P_{\mathrm{NH}_{3}}\right.$ $=2.0 \times 10^{-9}$ Torr $\left.\times 60 \mathrm{~s}\right)$ was dosed at $250 \mathrm{~K}$ on an oxygen-covered $\left(\theta_{\mathrm{O}}=0.21 \mathrm{MLE}\right) \mathrm{Ag}(111)$ surface, where oxygen was delivered by ozone exposure either at $140 \mathrm{~K}$ (multicolored spectra) or at $473 \mathrm{~K}$ (gray-colored spectra).

between these different sets of spectra is the temperature of oxygen delivery. While the oxygen delivery at $140 \mathrm{~K}$ (multicolored spectra) led to surface atomic oxygen $\left(\mathrm{O}_{\mathrm{a}}\right)$ species on $\operatorname{Ag}(111)$, oxygen delivery at $473 \mathrm{~K}$ (gray spectra) resulted in the formation of a $\mathrm{p}(5 \times 1)$ surface oxide.

Multicolored TPRS spectra in Figure 6 corresponding to the presence of surface atomic oxygen $\left(\mathrm{O}_{\mathrm{a}}\right)$ species on $\operatorname{Ag}(111)$ obtained via oxygen delivery at $140 \mathrm{~K}$ revealed the obvious reaction between surface oxygen species and ammonia yielding SCO products such as $\mathrm{N}_{2}$ (red), $\mathrm{NO}$ (blue), and $\mathrm{N}_{2} \mathrm{O}$ (green) in a wide temperature range between 300 and $450 \mathrm{~K}$. In addition, water desorption within the same temperature range was also in line with the $\mathrm{N}-\mathrm{H}$ bond activation and hydrogen abstraction from ammonia by surface oxygen atoms on $\operatorname{Ag}(111)$. Neither unreacted oxygen (black spectrum in Figure 6) nor $\mathrm{NO}_{2}$ formation (see Figure $\mathrm{S} 3$, Supporting Information) were detectable for the multicolored TPRS data. Molecular ammonia desorption was not also observed as a result of the $\mathrm{NH}_{3}$ dosage temperature $(250 \mathrm{~K})$, which is above the desorption temperature of the first monolayer of ammonia on clean $\mathrm{Ag}(111)$ (see Figure S3).

On the other hand, for the gray-colored TPRS data given in Figure 6 corresponding to the interaction of ammonia with the 
$p(5 \times 1)$ oxide overlayer (confirmed by LEED), a very limited extent of reaction between ammonia and oxygen was observable. The strikingly intense desorption signal of the unreacted oxygen species at $537 \mathrm{~K}$ was consistent with the limited ammonia oxidation by the oxide overlayer. A similar behavior was also reported by Madix and co-workers for $\mathrm{CO}$ oxidation on $\mathrm{Ag}(111)$, suggesting that the silver oxide overlayer was not the most reactive phase for the $\mathrm{CO}$ oxidation reaction. $^{72}$ Thus, comparative analysis of the TPRS data shown in Figure 6 pointed to the fact that surface atomic oxygen $\left(\mathrm{O}_{\mathrm{a}}\right)$ on $\mathrm{Ag}(111)$ could readily activate $\mathrm{N}-\mathrm{H}$ bond cleavage in $\mathrm{NH}_{3}$, while ordered silver oxide $\left(\mathrm{O}_{\text {ox }}\right)$ overlayers had limited activity for ammonia oxidation.

$\mathrm{NH}_{3}$ SCO reactions on the $\mathrm{Ag}(111)$ single-crystal surface containing different quantities of oxygen (delivered by ozone exposure at $140 \mathrm{~K}$ ) were performed, and the corresponding TPRS spectra of the selected products (i.e., $\mathrm{N}_{2}, \mathrm{NO}$, and $\mathrm{N}_{2} \mathrm{O}$ ) are given in Figure 7. Alternative depictions of the same set of data are also provided in Figure S4 and S5 (Supporting
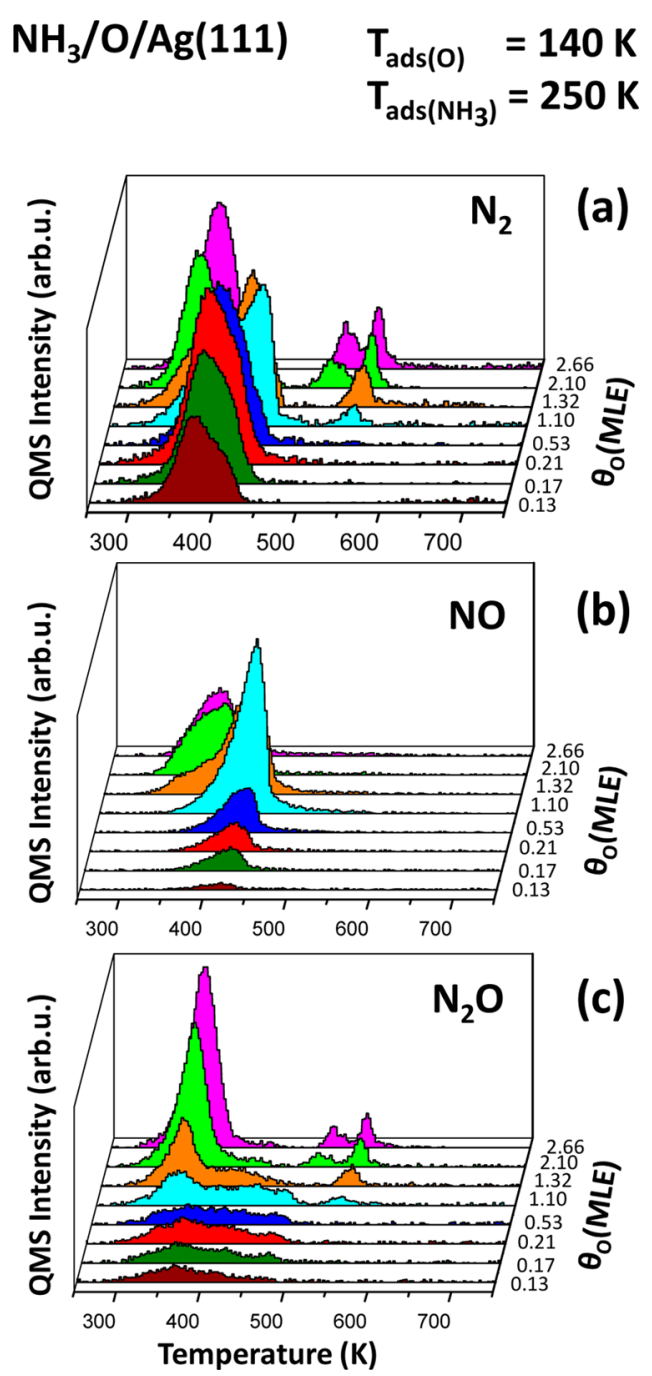

Figure 7. TPRS profiles of various ammonia $\mathrm{SCO}$ reaction products (i.e., $\mathrm{N}_{2}, \mathrm{NO}$, and $\mathrm{N}_{2} \mathrm{O}$ ) for the reaction between ammonia and oxygen-precovered $\operatorname{Ag}(111)$ surfaces as a function of the oxygen coverage. For all of the data, oxygen was delivered on $\mathrm{Ag}(111)$ by ozone exposure at $140 \mathrm{~K}$, while $\mathrm{NH}_{3}$ was delivered using an identical ammonia exposure at $250 \mathrm{~K}\left(P_{\mathrm{NH}_{3}}=2.0 \times 10^{-9}\right.$ Torr $\left.\times 60 \mathrm{~s}\right)$.
Information). Integrated desorption signals of the relevant products in Figure 7 were also calculated (after compensating for the interferences between various desorption signals due to mass spectroscopic fragmentation). These results are presented as histograms in Figure 8, revealing relative ammonia SCO

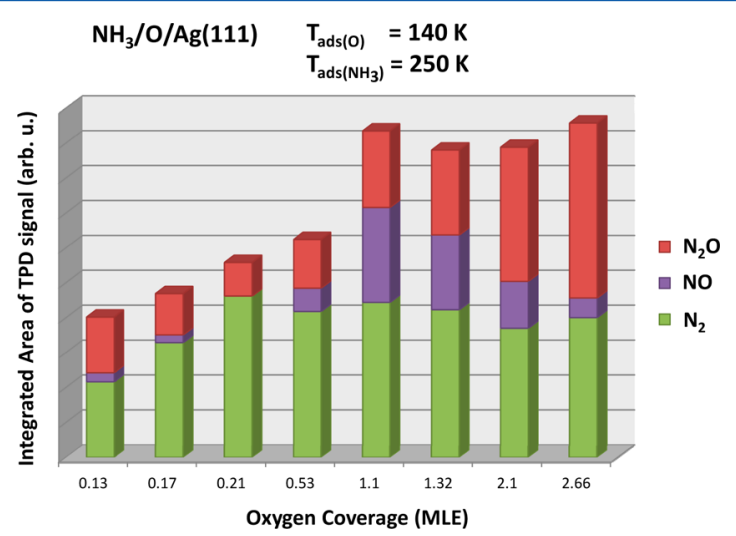

Figure 8. Integrated TPD desorption signals for the main ammonia SCO products (i.e., $\mathrm{N}_{2}, \mathrm{NO}$, and $\mathrm{N}_{2} \mathrm{O}$ ) on an $\mathrm{O} / \mathrm{Ag}(111)$ surface as a function of the oxygen coverage extracted from the TPRS data given in Figure 7. See the text for details.

selectivity for dissimilar oxygen coverages. To calculate total integrated TPRS signals of $\mathrm{N}_{2} \mathrm{O}$ in Figure 8, mass spectroscopic fragments of $\mathrm{N}_{2} \mathrm{O}$ other than $\mathrm{m} / z=44$ were also considered. By referring to the National Institute of Standards and Technology (NIST) mass spectroscopy database, ${ }^{73}$ relative intensities of the main fragments of $\mathrm{N}_{2} \mathrm{O}$ were obtained as $100 \%, 32 \%$, and $11 \%$ for $m / z=44,30$, and 28 , respectively. Accordingly, the integrated $m / z=44$ desorption signal was multiplied by a factor of 1.43. On the other hand, the contributions of $\mathrm{N}_{2} \mathrm{O}$ to the $\mathrm{NO}$ and $\mathrm{N}_{2}$ integrated signals were subtracted (removed) from the integrated $\mathrm{m} / z=30$ and 28 signals. As can be seen in Figures 7 and 8, the main ammonia SCO product for low oxygen coverages (i.e., $0.13 \mathrm{MLE}<\theta_{\mathrm{O}}<$ $1.10 \mathrm{MLE}$ ) was clearly $\mathrm{N}_{2}$ and the maximum $\mathrm{N}_{2}$ formation was obtained for $\theta_{\mathrm{O}}=0.21 \mathrm{MLE}$. It is also apparent that $\mathrm{NO}$ selectivity increased drastically for $\theta_{\mathrm{O}}=1.10 \mathrm{MLE}$ and became comparable to that of $\mathrm{N}_{2}$.

It is worth mentioning that the $\mathrm{N}_{2}$ desorption maxima shifted to higher temperatures for $\theta_{\mathrm{O}} \geq 1.10 \mathrm{MLE}$ (Figure $7 \mathrm{a}$ and Figure S4a, Supporting Information) and additional $\mathrm{N}_{2}$ desorption states also became visible. This observation was concomitant with the appearance of excess oxygen desorption associated with surface and subsurface/bulk oxide states (Figure S5, Supporting Information). Thus, it can be argued that formation of oxide species abundant in oxygen led to an attractive interaction between oxygen species and atomic nitrogen, resulting in the stabilization of the atomic nitrogen species generated by $\mathrm{N}-\mathrm{H}$ bond activation of $\mathrm{NH}_{3}$ and a shift in the $\mathrm{N}_{2}$ desorption maxima to higher temperatures. Furthermore, generation of additional high-temperature $\mathrm{N}_{2}$ desorption states at elevated oxygen coverages can also be attributed to the increasing heterogeneity of the adsorption sites of the substrate surface due to the formation of bulklike silver oxide.

Furthermore, unreacted $\mathrm{NH}_{3}$ was also monitored (Figure S6, Supporting Information) for the set of experiments presented in Figure 7. These results revealed limited amounts of ammonia desorption (i.e., a lack of the presence of excess ammonia), 
suggesting a high conversion of ammonia for the particular set of experimental conditions chosen for Figure 7.

It is worth mentioning that IRAS measurements were also performed at $250 \mathrm{~K}$ for SCO of ammonia on the atomic oxygen $\left(\mathrm{O}_{\mathrm{a}}\right)$ covered $\mathrm{Ag}(111)$ surface using experimental conditions (coverages) similar to the ones chosen for the TPRS experiments given in Figure 7. However, no IRAS signals were detected, possibly due to the unfavorable adsorption geometry or small IR absorption cross sections of the reactants and products lying possibly close to parallel to the surface.

The overall reactivity and selectivity trends of ammonia SCO on $\mathrm{O} / \mathrm{Ag}(111)$ as a function of the adsorption temperature, oxygen surface coverage, and nature of the oxygen species deduced from the currently presented experimental findings are summarized in Scheme 1.

Scheme 1. Reactivity and Selectivity Trends of Ammonia $\mathrm{SCO}$ on $\mathrm{O} / \mathrm{Ag}(111)$ as a Function of the Oxygen Coverage and Temperature

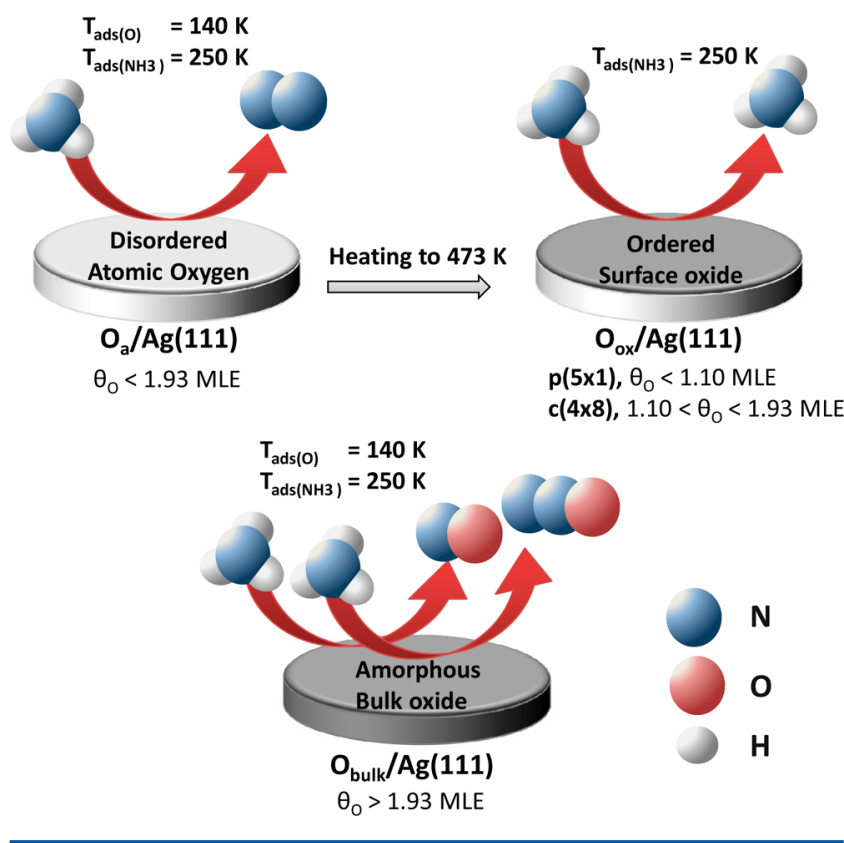

\section{CONCLUSIONS}

In the current study, SCO of ammonia on $\mathrm{O} / \mathrm{Ag}(111)$ was investigated by utilizing a multitude of surface-sensitive spectroscopic and diffraction techniques where a unique oxygen delivery agent (i.e., ozone) was utilized under UHV conditions, eliminating the need for high-pressure $\mathrm{O}_{2}$ exposures. TPD/ TPRS, XPS, and LEED data suggest that a variety of oxygen species can be generated on the $\operatorname{Ag}(111)$ surface upon ozone adsorption, such as atomic (chemisorbed) oxygen, surface oxide, and bulklike oxide species. Indications of oxygen transport to the subsurface region of silver at elevated ozone exposures were also detected. Oxygen overlayers prepared via ozone exposure at $140 \mathrm{~K}$ in UHV led to disordered overlayers (in the form of either atomic oxygen or bulklike silver oxide) for all oxygen coverages, while annealing of these overlayers for intermediate oxygen coverages at $473 \mathrm{~K}$ resulted in the formation of ordered surface oxides with $\mathrm{p}(5 \times 1)$ and $\mathrm{c}(4 \times 8)$ structures. The clean $\operatorname{Ag}(111)$ surface was found to be incapable of activating $\mathrm{N}-\mathrm{H}$ bonds of ammonia under UHV conditions in the absence of ozone exposure. Disordered atomic oxygen overlayers prepared on $\operatorname{Ag}(111)$ at $140 \mathrm{~K}$ for $\theta_{\mathrm{O}}$ $<1.10$ MLE were found to be highly selective in SCO of ammonia, producing $\mathrm{N}_{2}$ as the dominant product. On the other hand, ordered $\mathrm{p}(5 \times 1)$ and $\mathrm{c}(4 \times 8)$ surface oxide overlayers on $\mathrm{Ag}(111)$ prepared via ozone adsorption at $473 \mathrm{~K}$ were found to be almost entirely inactive in $\mathrm{SCO}$ where $\mathrm{NH}_{3}$ and $\mathrm{O}_{2}$ desorbed in an intact manner in TPRS experiments. It was observed that extreme oxygen exposures on $\operatorname{Ag}(111)\left(\theta_{\mathrm{O}}>\right.$ $1.93 \mathrm{MLE})$ at $140 \mathrm{~K}$ led to bulklike silver oxide species with poor $\mathrm{N}_{2}$ selectivity in ammonia $\mathrm{SCO}$ and increasing extent of formation of toxic pollutants such as $\mathrm{NO}$ and $\mathrm{N}_{2} \mathrm{O}$. Currently presented experimental findings on the $\mathrm{Ag}(111)$ single-crystal model catalyst surface reveal valuable insights as well as new structure-functionality relationships at the molecular level regarding the reactivity of oxygen species in ammonia SCO. These findings may also be relevant to other crucial heterogeneous catalytic oxidation/partial oxidation/oxidative coupling processes of $\mathrm{CO}$, alkenes, and alcohols.

\section{ASSOCIATED CONTENT}

S Supporting Information

The Supporting Information is available free of charge on the ACS Publications website at DOI: 10.1021/acs.jpcc.7b08291.

$\mathrm{Ag} 3 \mathrm{~d}$ XPS spectra for clean $\operatorname{Ag}(111), \mathrm{O}_{\mathrm{a}} / \operatorname{Ag}(111)$, and $\mathrm{O}_{\text {bulk }} / \mathrm{Ag}(111)$, TPD profiles for the $\mathrm{H}_{2} \mathrm{O}(\mathrm{m} / z=18)$ desorption channel for the data given in Figure 4, TPRS profiles for the $\mathrm{NO}_{2}(m / z=46)$ and $\mathrm{NH}_{3}(m / z=17)$ desorption channels for the data given in Figure 6, alternative depiction of the TPRS profiles of various ammonia SCO reaction products given in Figure 7 , and TPRS profiles for the $\mathrm{O}_{2}(\mathrm{~m} / z=32), \mathrm{NH}_{3}$ and $\mathrm{OH}(\mathrm{m} / z$ $=17)$, and $\mathrm{H}_{2} \mathrm{O}(m / z=18)$ desorption channels for the data given in Figure 7 (PDF)

\section{AUTHOR INFORMATION}

\section{Corresponding Author}

*E-mail: ozensoy@fen.bilkent.edu.tr.

ORCID $\odot$

Mustafa Karatok: 0000-0001-5509-5463

Evgeny I. Vovk: 0000-0001-9340-0027

Present Address

"E.I.V.: ShanghaiTech University, 201210 Shanghai, China.

Notes

The authors declare no competing financial interest.

\section{ACKNOWLEDGMENTS}

We acknowledge the financial support from the Scientific and Technological Research Council of Turkey (TUBITAK) (Project Code 112T589). We also gratefully acknowledge Prof. Mehmet Erbudak (Physics Department, ETH Zurich) for his contributions regarding the construction of the UHV experimental setup. We also acknowledge the scientific collaboration with the TARLA project founded by the Ministry of Development of Turkey under Grant No. DPT2006K120470.

\section{REFERENCES}

(1) Jabłońska, M.; Palkovits, R. Copper Based Catalysts for the Selective Ammonia Oxidation into Nitrogen and Water VapourRecent Trends and Open Challenges. Appl. Catal., B 2016, 181, 332351. 
(2) Park, S. J.; Jin, S. Y. Effect of Ozone Treatment on Ammonia Removal of Activated Carbons. J. Colloid Interface Sci. 2005, 286 (1), 417-419.

(3) Eurostat Statistics Explained. http://ec.europa.eu/eurostat/ statistics-explained/index.php/Agriculture_-_ammonia_emission_ statistics (accessed Aug 1, 2017).

(4) Fangmeier, A.; Hadwiger-Fangmeier, A.; Van der Eerden, L.; Jäger, H. J. Effects of Atmospheric Ammonia on Vegetation-a Review. Environ. Pollut. 1994, 86 (1), 43-82.

(5) Busca, G.; Pistarino, C. Abatement of Ammonia and Amines from Waste Gases: a Summary. J. Loss Prev. Process Ind. 2003, 16 (2), 157163.

(6) Gang, L.; Anderson, B. G.; Van Grondelle, J.; Van Santen, R. A.; Van Gennip, W. J. H.; Niemantsverdriet, J. W.; Kooyman, P. J.; Knoester, A.; Brongersma, H. H. Alumina-Supported $\mathrm{Cu}-\mathrm{Ag}$ Catalysts for Ammonia Oxidation to Nitrogen at Low Temperature. J. Catal. 2002, 206 (1), 60-70.

(7) Davies, P. R.; Newton, N. G. The Chemisorption and Decomposition of Pyridine and Ammonia at Clean and Oxidised $\mathrm{Al}$ (111) Surfaces. Surf. Sci. 2003, 546 (2), 149-158.

(8) Lescop, B.; Galtayries, A.; Fanjoux, G. Thermal Chemistry of $\mathrm{NH}_{3}$ on Oxygen-Pretreated $\mathrm{Ni}(111)$ Studied by Metastable Induced Electron Spectroscopy and Ultraviolet Photoelectron Spectroscopy. J. Phys. Chem. B 2004, 108 (36), 13711-13718.

(9) Ludvíková, J.; Jabłońska, M.; Jirátová, K.; Chmielarz, L.; Balabánová, J.; Kovanda, F.; Obalová, L. Co-Mn-Al Mixed Oxides as Catalysts for Ammonia Oxidation to $\mathrm{N}_{2} \mathrm{O}$. Res. Chem. Intermed. 2016, 42 (3), 2669-2690.

(10) Zhang, Q.; Wang, H.; Ning, P.; Song, Z.; Liu, X.; Duan, Y. In situ DRIFTS Studies on $\mathrm{CuO}-\mathrm{Fe}_{2} \mathrm{O}_{3}$ Catalysts for Low Temperature Selective Catalytic Oxidation of Ammonia to Nitrogen. Appl. Surf. Sci. 2017, 419, 733-743.

(11) Bradley, J. M.; Hopkinson, A.; King, D. A. Control of a Biphasic Surface Reaction by Oxygen Coverage: the Catalytic Oxidation of Ammonia over Pt $\{100\}$. J. Phys. Chem. 1995, 99 (46), 17032-17042.

(12) Gang, L.; Anderson, B. G.; van Grondelle, J.; van Santen, R. A. Intermediate Species and Reaction Pathways for the Oxidation of Ammonia on Powdered Catalysts. J. Catal. 2001, 199 (1), 107-114.

(13) Long, R. Q.; Yang, R. T. Noble Metal (Pt, Rh, Pd) Promoted Fe-ZSM-5 for Selective Catalytic Oxidation of Ammonia to $\mathrm{N}_{2}$ at Low Temperatures. Catal. Lett. 2002, 78 (1-4), 353-357.

(14) Gang, L.; Anderson, B. G.; Van Grondelle, J.; Van Santen, R. A. Low Temperature Selective Oxidation of Ammonia to Nitrogen on Silver-Based Catalysts. Appl. Catal., B 2003, 40 (2), 101-110.

(15) Weststrate, C. J.; Bakker, J. W.; Rienks, E. D. L.; Martinez, J. R.; Vinod, C. P.; Lizzit, S.; Petaccia, L.; Baraldi, A.; Nieuwenhuys, B. E. Selective $\mathrm{NH}_{3}$ Oxidation on (110) and (111) Iridium Surfaces. J. Catal. 2005, 235 (1), 92-102.

(16) Gong, J.; Ojifinni, R. A.; Kim, T. S.; White, J. M.; Mullins, C. B. Selective Catalytic Oxidation of Ammonia to Nitrogen on Atomic Oxygen Precovered Au (111). J. Am. Chem. Soc. 2006, 128 (28), 9012-9013.

(17) Chmielarz, L.; Jabłońska, M. Advances in Selective Catalytic Oxidation of Ammonia to Dinitrogen: a Review. RSC Adv. 2015, 5 (54), 43408-43431.

(18) Lippits, M. J.; Gluhoi, A. C.; Nieuwenhuys, B. E. A Comparative Study of the Selective Oxidation of $\mathrm{NH}_{3}$ to $\mathrm{N}_{2}$ over Gold, Silver and Copper Catalysts and the Effect of Addition of $\mathrm{Li}_{2} \mathrm{O}$ and $\mathrm{CeO}_{x}$. Catal. Today 2008, 137 (2), 446-452.

(19) Yang, M.; Wu, C.; Zhang, C.; He, H. Selective Oxidation of Ammonia over Copper-Silver-Based Catalysts. Catal. Today 2004, 90 (3), 263-267.

(20) Zhang, L.; Zhang, C.; He, H. The Role of Silver Species on Ag/ $\mathrm{Al}_{2} \mathrm{O}_{3}$ Catalysts for the Selective Catalytic Oxidation of Ammonia to Nitrogen. J. Catal. 2009, 261 (1), 101-109.

(21) Dean, M.; Bowker, M. Adsorption Studies on Catalysts under UHV/HV Conditions: I. Oxygen Adsorption on Alumina Supported Silver. Appl. Surf. Sci. 1988, 35 (1), 27-40.
(22) Rovida, G.; Pratesi, F.; Maglietta, M.; Ferroni, E. Effects of Oxygen on Silver Surface Structure. J. Vac. Sci. Technol. 1972, 9 (2), 796-799.

(23) Rovida, G.; Pratesi, F.; Maglietta, M.; Ferroni, E. Chemisorption of Oxygen on the Silver (111) Surface. Surf. Sci. 1974, 43 (1), 230256.

(24) Engelhardt, H. A.; Menzel, D. Adsorption of Oxygen on Silver Single Crystal Surfaces. Surf. Sci. 1976, 57 (2), 591-618.

(25) Grant, R. B.; Lambert, R. M. Basic Studies of the Oxygen Surface Chemistry of Silver: Chemisorbed Atomic and Molecular Species on Pure Ag (111). Surf. Sci. 1984, 146 (1), 256-268.

(26) Campbell, C. T. Atomic and Molecular Oxygen Adsorption on Ag (111). Surf. Sci. 1985, 157 (1), 43-60.

(27) Bukhtiyarov, V. I.; Boronin, A. I.; Savchenko, V. I. Two Oxygen States and the Role of Carbon in Partial Oxidation of Ethylene over Silver. Surf. Sci. 1990, 232 (1-2), L205-L209.

(28) Bao, X.; Muhler, M.; Schedel-Niedrig, T.; Schlögl, R. Interaction of Oxygen with Silver at High Temperature and Atmospheric Pressure: a Spectroscopic and Structural Analysis of a Strongly Bound Surface Species. Phys. Rev. B: Condens. Matter Mater. Phys. 1996, 54 (3), 2249.

(29) Bukhtiyarov, V. I.; Kaichev, V. V.; Prosvirin, I. P. Oxygen Adsorption on Ag (111): X-ray Photoelectron Spectroscopy (XPS), Angular Dependent X-ray Photoelectron Spectroscopy (ADXPS) and Temperature-Programmed Desorption (TPD) Studies. J. Chem. Phys. 1999, 111 (5), 2169-2175.

(30) Bukhtiyarov, V. I.; Hävecker, M.; Kaichev, V. V.; Knop-Gericke, A.; Mayer, R. W.; Schlögl, R. Atomic Oxygen Species on Silver: Photoelectron Spectroscopy and X-ray Absorption Studies. Phys. Rev. B: Condens. Matter Mater. Phys. 2003, 67 (23), 235422.

(31) Huang, W. X.; White, J. M. Revisiting $\mathrm{NO}_{2}$ on Ag (111): A Detailed TPD and RAIRS Study. Surf. Sci. 2003, 529 (3), 455-470.

(32) Reicho, A.; Stierle, A.; Costina, I.; Dosch, H. StranskiKrastanov like Oxide Growth on Ag (111) at Atmospheric Oxygen Pressures. Surf. Sci. 2007, 601 (4), L19-L23.

(33) Li, W. X.; Stampfl, C.; Scheffler, M. Subsurface Oxygen and Surface Oxide Formation at Ag (111): A Density-Functional Theory Investigation. Phys. Rev. B: Condens. Matter Mater. Phys. 2003, 67 (4), 045408 .

(34) Michaelides, A.; Bocquet, M. L.; Sautet, P.; Alavi, A.; King, D. A. Structures and Thermodynamic Phase Transitions for Oxygen and Silver Oxide Phases on Ag (111). Chem. Phys. Lett. 2003, 367 (3), 344-350.

(35) Xu, Y.; Greeley, J.; Mavrikakis, M. Effect of Subsurface Oxygen on the Reactivity of the Ag (111) Surface. J. Am. Chem. Soc. 2005, 127 (37), 12823-12827.

(36) Schmid, M.; Reicho, A.; Stierle, A.; Costina, I.; Klikovits, J.; Kostelnik, P.; Dubay, O.; Kreesse, G.; Gustafson, J.; Lundgren, E.; et al. Structure of $\mathrm{Ag}(111)-\mathrm{p}(4 \times 4)-\mathrm{O}$ : No Silver Oxide. Phys. Rev. Lett. 2006, 96 (14), 146102.

(37) Schnadt, J.; Michaelides, A.; Knudsen, J.; Vang, R. T.; Reuter, K.; Lægsgaard, E.; Scheffler, M.; Besenbacher, F. Revisiting the Structure of the p (4×4) Surface Oxide on Ag (111). Phys. Rev. Lett. 2006, 96 (14), 146101.

(38) Schnadt, J.; Knudsen, J.; Hu, X. L.; Michaelides, A.; Vang, R. T.; Reuter, K.; Li, Z.; Lægsgaard, E.; Scheffler, M.; Besenbacher, F. Experimental and Theoretical Study of Oxygen Adsorption Structures on Ag (111). Phys. Rev. B: Condens. Matter Mater. Phys. 2009, 80 (7), 075424 .

(39) Rocha, T. C.; Oestereich, A.; Demidov, D. V.; Hävecker, M.; Zafeiratos, S.; Weinberg, G.; Bukhtiyarov, V. I.; Knop-Gericke, A.; Schlögl, R. The Silver-Oxygen System in Catalysis: New Insights by Near Ambient Pressure X-ray Photoelectron Spectroscopy. Phys. Chem. Chem. Phys. 2012, 14 (13), 4554-4564.

(40) Günther, S.; Böcklein, S.; Wintterlin, J.; Niño, M. A.; Mentes, T. O.; Locatelli, A. Locating Catalytically Active Oxygen on Ag (111)-A Spectromicroscopy Study. ChemCatChem 2013, 5 (11), 3342-3350.

(41) Martin, N. M.; Klacar, S.; Gronbeck, H.; Knudsen, J.; Schnadt, J.; Blomberg, S.; Gustafson, J.; Lundgren, E. High-Coverage Oxygen- 
Induced Surface Structures on Ag (111). J. Phys. Chem. C 2014, 118 (28), 15324-15331.

(42) Derouin, J.; Farber, R. G.; Heslop, S. L.; Killelea, D. R. Formation of Surface Oxides and $\mathrm{Ag}_{2} \mathrm{O}$ Thin Films with Atomic Oxygen on Ag (111). Surf. Sci. 2015, 641, L1-L4.

(43) Jones, T. E.; Rocha, T. C.; Knop-Gericke, A.; Stampfl, C.; Schlögl, R.; Piccinin, S. Thermodynamic and Spectroscopic Properties of Oxygen on Silver under an Oxygen Atmosphere. Phys. Chem. Chem. Phys. 2015, 17 (14), 9288-9312.

(44) Heine, C.; Eren, B.; Lechner, B. A.; Salmeron, M. A Study of the $\mathrm{O} / \mathrm{Ag}$ (111) System with Scanning Tunneling Microscopy and X-ray Photoelectron Spectroscopy at Ambient Pressures. Surf. Sci. 2016, 652, 51-57.

(45) Derouin, J.; Farber, R. G.; Turano, M. E.; Iski, E. V.; Killelea, D. R. Thermally Selective Formation of Subsurface Oxygen in Ag (111) and Consequent Surface Structure. ACS Catal. 2016, 6 (7), 46404646.

(46) Andryushechkin, B. V.; Shevlyuga, V. M.; Pavlova, T. Y. V. E.; Zhidomirov, G. M.; Eltsov, K. N. Structural Transformations on an Oxidized Ag (111) Surface. JETP Lett. 2017, 105 (5), 292-296.

(47) Carlisle, C. I.; King, D. A.; Bocquet, M. L.; Cerdá, J.; Sautet, P. Imaging the Surface and the Interface Atoms of an Oxide Film on $\mathrm{Ag}$ (111) by Scanning Tunneling Microscopy: Experiment and Theory. Phys. Rev. Lett. 2000, 84 (17), 3899.

(48) Bao, X.; Barth, J. V.; Lehmpfuhl, G.; Schuster, R.; Uchida, Y.; Schlögl, R; Ertl, G. Oxygen-Induced Restructuring of Ag (111). Surf. Sci. 1993, 284 (1-2), 14-22.

(49) Michaelides, A.; Reuter, K.; Scheffler, M. When Seeing is not Believing: Oxygen on Ag (111), a Simple Adsorption System? J. Vac. Sci. Technol., A 2005, 23 (6), 1487-1497.

(50) Bare, S. R.; Griffiths, K.; Lennard, W. N.; Tang, H. T. Generation of Atomic Oxygen on $\mathrm{Ag}$ (111) and $\mathrm{Ag}$ (110) Using $\mathrm{NO}_{2}$ : a TPD, LEED, HREELS, XPS and NRA Study. Surf. Sci. 1995, 342 (1-3), 185-198.

(51) Popova, I.; Zhukov, V.; Yates, J. T. Comparative Study of Al

(111) Oxidation with $\mathrm{O}_{3}$ and $\mathrm{O}_{2}$. Surf. Sci. 2002, 518 (1), 39-48.

(52) Parker, D. H.; Koel, B. E. Chemisorption of High Coverages of Atomic Oxygen on the Pt (111), Pd (111), and Au (111) Surfaces. J. Vac. Sci. Technol., A 1990, 8 (3), 2585-2590.

(53) Saliba, N. A.; Tsai, Y. L.; Panja, C.; Koel, B. E. Oxidation of Pt (111) by Ozone $\left(\mathrm{O}_{3}\right)$ under UHV Conditions. Surf. Sci. 1999, 419 (2), 79-88.

(54) Saliba, N.; Parker, D. H.; Koel, B. E. Adsorption of Oxygen on $\mathrm{Au}$ (111) by Exposure to Ozone. Surf. Sci. 1998, 410 (2), 270-282.

(55) Karatok, M.; Vovk, E. I.; Shah, A. A.; Turksoy, A.; Ozensoy, E. Acetaldehyde Partial Oxidation on the Au (111) Model Catalyst Surface: C-C Bond Activation and Formation of Methyl Acetate as an Oxidative Coupling Product. Surf. Sci. 2015, 641, 289-293.

(56) Backx, C.; De Groot, C. P. M.; Biloen, P. Adsorption of Oxygen on Ag (110) Studied by High Resolution ELS and TPD. Surf. Sci. 1981, 104 (1), 300-317.

(57) Reichelt, R.; Günther, S.; Rößler, M.; Wintterlin, J.; Kubias, B.; Jakobi, B.; Schlögl, R. High-Pressure STM of the Interaction of Oxygen with Ag (111). Phys. Chem. Chem. Phys. 2007, 9 (27), 35903599.

(58) Bao, X.; Muhler, M.; Pettinger, B.; Schlögl, R.; Ertl, G. On the Nature of the Active State of Silver During Catalytic Oxidation of Methanol. Catal. Lett. 1993, 22 (3), 215-225.

(59) Fisher, G. B. The Electronic Structure of Two Forms of Molecular Ammonia Adsorbed on Pt (111). Chem. Phys. Lett. 1981, 79 (3), 452-458.

(60) Kay, B. D.; Lykke, K. R.; Creighton, J. R.; Ward, S. J. The Influence of Adsorbate-Absorbate Hydrogen Bonding in Molecular Chemisorption: $\mathrm{NH}_{3}, \mathrm{HF}$, and $\mathrm{H}_{2} \mathrm{O}$ on $\mathrm{Au}$ (111). J. Chem. Phys. 1989, 91 (8), 5120-5121.

(61) Van Hardeveld, R. M.; Van Santen, R. A.; Niemantsverdriet, J. W. The Adsorption of $\mathrm{NH}_{3}$ on $\mathrm{Rh}$ (111). Surf. Sci. 1996, 369 (1-3), $23-35$.
(62) Santra, A. K.; Min, B. K.; Yi, C. W.; Luo, K.; Choudhary, T. V.; Goodman, D. W. Decomposition of $\mathrm{NH}_{3}$ on $\mathrm{Ir}$ (100): A Temperature Programmed Desorption Study. J. Phys. Chem. B 2002, 106 (2), 340344.

(63) Chorkendorff, I.; Niemantsverdriet, J. W. Concepts of Modern Catalysis and Kinetics; John Wiley \& Sons: Weinheim, Germany, 2003.

(64) Gland, J. L.; Sexton, B. A.; Mitchell, G. E. Ammonia Adsorption on the Ag (110) Surface. Surf. Sci. 1982, 115 (3), 623-632.

(65) Sälli, E.; Martiskainen, S.; Halonen, L. Computational Study of the Vibrational Structure of the Ammonia Molecule Adsorbed on the FCC (111) Transition Metal Surfaces. J. Phys. Chem. C 2012, 116 (28), 14960-14969.

(66) Xu, Z.; Hanley, L.; Yates, J. T., Jr Layer Interactions Between Dissimilar Adsorbates. $\mathrm{NH}_{3}$ Layers on Chemisorbed $\mathrm{CO}$ on $\mathrm{Ni}$ (111): A Reflection Infrared Study. J. Chem. Phys. 1992, 96 (2), 1621-1627.

(67) Rodriguez, J.; Kuhn, W. K.; Truong, C. M.; Goodman, D. W. A FT-IRAS Study of Ammonia Adsorbed on Ru (0001). Surf. Sci. 1992, 271 (3), 333-339.

(68) Villegas, I.; Weaver, M. J. Infrared Spectroscopy of Model Electrochemical Interfaces in Ultrahigh Vacuum: Interfacial Cation Solvation by Ammonia on Pt (111). Surf. Sci. 1996, 367 (2), 162-176.

(69) Pradier, C. M.; Adamski, A.; Méthivier, C.; Louis-Rose, I. Interaction of $\mathrm{NH}_{3}$ and Oxygen with $\mathrm{Cu}(110)$, Investigated by FTIRAS. J. Mol. Catal. A: Chem. 2002, 186 (1), 193-201.

(70) Fukushima, T.; Song, M. B.; Ito, M. Local Work-Function Changes of Pt (111) Studied by STM and IRAS: Coadsorption of Clwith $\mathrm{H}_{3} \mathrm{O}^{+}$, NO, and CO Molecules. Surf. Sci. 2000, 464 (2), 193-199.

(71) Gohndrone, J. M.; Olsen, C. W.; Backman, A. L.; Gow, T. R.; Yagasaki, E.; Masel, R. I. Ammonia Adsorption and Decomposition on Several Faces of Platinum. J. Vac. Sci. Technol., A 1989, 7 (3), 19861990.

(72) Klust, A.; Madix, R. J. Mesoscopic Restructuring and Mass Transport of Metal Atoms During Reduction of the Ag (111)-p (4×4)-O Surface with CO. J. Chem. Phys. 2007, 126 (8), 084707.

(73) NIST Chemistry WebBook. http://webbook.nist.gov/cgi/ cbook.cgi? $\mathrm{ID}=\mathrm{C} 10024972 \&$ Units $=$ SI\&Mask=200\#Mass-Spec $\quad($ ac cessed Aug 1, 2017). 